\title{
MINERALOGICAL CHARACTERIZATION OF MARTIAN JEZERO CRATER FROM MRO CRISM HYPERSPECTRAL IMAGES
}

\author{
Shuanggen Jin ${ }^{\mathrm{a},}$, Yi Yang ${ }^{\mathrm{a}, \mathrm{b}}$ \\ ${ }^{a}$ Shanghai Astronomical Observatory, Chinese Academy of Sciences, Shanghai 200030, China \\ sgjin@shao.ac.cn \\ ${ }^{\mathrm{b}}$ University of Chinese Academy of Sciences, Beijing 100049, China \\ yiyang@shao.ac.cn
}

KEY WORDS: Planetary mapping, Hyper spectral, Minerals, Mars

\begin{abstract}
:
Martian mineral detection and mapping can provide important information and constraints on Martian aqueous history, which can be used to assess the potential habitability of Mars. The key parameters to Martian aqueous alteration are the depth and extent of the Martian hydrous mineral. Therefore, it is important to know detailed minerals and chemical induction of the existence of water on the Martian surface at past or present. The Jezero crater located in the Nili Fossae region of Mars is the once-flooded crater, which has rich fan-delta deposit clays. It is a good case to study the clays and mineral components at Jezero crater, so as to know the geogloical processes and evolution on Mars. The Compact Reconnaissance Imaging Spectrometer for Mars (CRISM) aboard the Mars Reconnaissance Orbiter (MRO) is a visible and near infrared spectrometer with enhanced spectral resolution, which provides an opportunity to map detailed and large-area mineralogy on Mars. In this paper, CRISM nearinfrared spectral data are analyzed using the mixture tuned filtering(MTMF)along with spectral angle mapper (SAM), and mineral components at Martian Jezero region are recognized, including the phyllosilicate, carbonate, nitrates and tectosil. Some detailed characteristics and implications of minerals at Martian Jezero crater are further studied and discussed, including implications on Martian climate change and geological evolution.
\end{abstract}

\section{INTRODUCTION}

Mars and other solid celestial bodies, also called the terrestrial planets, are primarily composed of rock with a given mass of minerals. Identification of mineral components at different regions on Mars is crucial to understand the Martian geology, hydrology and environmental changes. Meanwhile some minerals can form only under the condition of existence of water, such as carbonate and sulfate. Therefore, detection of these minerals could provide important information and constraints on Martian aqueous history, which can be used to assess the potential habitability of Mars. The Jezero crater located in the Nili Fossae region of Mars is a once-flooded crater, which has rich fan-delta deposit clays. It is a good case to study the mineral components at Jezero crater, so as to know the geological process and evolution on Mars. Previous investigations by the Observatoire pour l'Mine'ralogie, l'Eau, les Glaces, et l'Activite' (OMEGA) instrument on Mars Express provided the mineralogical analysis at this crater [1], but are restricted in less mineral species and lower spectral resolution. Considering spatial superiority, the Compact Reconnaissance Imaging Spectrometer for Mars (CRISM) aboard the Mars Reconnaissance Orbiter (MRO) is a visible and near infrared spectrometer with enhanced spectral resolution, which has high recognition capability of spatially widespread and mineralogical diverse alteration minerals and can detect the detailed and largearea Martian minerals, so as to further analyze the multiple aqueous environments on Mars. In this paper, using mixture tuned filtering (MTMF) and spectral angle mapping (SAM) based on CRISM near-infrared spectral data, we identify the detailed mineral classes and assess their abundance and infeasibility value in the Jezero Crater. Some implications of minerals at Martian Jezero crater related to the Martian climate and geological evolution are further studied and discussed. After briefly reviewing the geologic setting of the study area in section 2, observation data processing and methods are presented in section 3, and some results and discussion on Martian mineral species identification are shown in section 4 . Finally, some conclusions are given in Section 5.

\section{GEOMORPHOLOGY AND GEOLOGIC SETTING}

The Jezero crater locates in Nili fossae region on Mars with a diameter of $45 \mathrm{~km}$, which is rich in clay fluvial-lacustrine sediments and sedimentary deposits of hydrous minerals [2]. Clay-rich sedimentary deposits are often sites of organic matter preservation, and have therefore been considered for in-situ exploration by Mars Science Laboratory.

The first detailed distribution map of minerals on Mars was demonstrated by the Thermal Emission Spectrometer (TES) onboard Mars Global Surveyor (MGS) [3], which contributed to new insights of the surface environments on Mars. The exposure of some kind of rocks revealed the early aqueous history of the planet, like phyllosilicates preserving a record of water alteration with rocks on Mars. The diverse phyllosilicates, including a family of aqueous alteration products, had been identified, which was consistent with an early active hydrological system. The detected outcrops of crystalline gray hematite indicated the existence of chemical precipitation of iron-enriched aqueous fluids [4]. The identification of hydrated minerals gave the direct mineralogical evidence of the water on Mars [5]. Hydrated minerals, particularly phyllosilicates, were mostly exposed in the ancient terrain units, such as Noachian, which indicated the age correlation with specific mineral [6]. Although the diagnostic absorptions feature can be utilized for mineral identification, the more precise classification is needed to check the spectral angle [7]. However, the calculation of spectral angle requires the higher spectral resolution. Since the Mars Reconnaissance Orbiter (MRO) was launched on August 12,2005 , the available hyperspectral remote sensor onboard 
MRO can provide the spectral angle map for Mars. Therefore, the detailed minerals on Mars can be detected.

\section{DATA AND METHOD}

The Compact Reconnaissance Imaging Spectrometer for Mars (CRISM) aboard the Mars Reconnaissance Orbiter (MRO) is the first hyperspectral imager for Mars exploration, which aims at identifying the mineral on Mars. The CRISM has 544 channels to measure visible and infrared electromagnetic radiation from 370 to 3920 nanometers. Two spectrometers cover the wavelength ranging from 0.36 to $1.05 \mu \mathrm{m}(\mathrm{S})$ and 1.0 to $3.9 \mu \mathrm{m}(\mathrm{L})$, respectively. The CRISM has two kinds of operation modes: (1) a 72-channel mapping mode with $200 \mathrm{~m} /$ pixel spatial resolution and (2) a full 544-channel targeted mode with $15-38 \mathrm{~m} /$ pixel spatial resolution [8]. It can be used to search evidences of aqueous or hydrothermal activity, and characterize the composition, geology, and stratigraphy of surface features, particularly the presence of indicative minerals of aqueous alteration, e.g., phyllosilicates, carbonate, sulfate, salt and oxides, which can be chemically altered or formed in the presence of water. All of these minerals with specific visible-infrared spectral profiles can be found in the CRISM image.

In order to analyze the spectral characteristics, CRISM "L" spectrometer data are converted from calibrated radiance to apparent reflectance and $\mathrm{CO} 2$ absorption band is removed by using the "volcano scan" atmospheric correction. The Photometric Correction is applied to CRISM data through dividing by the cosine of the incidence angle in mainly order to correct the radiance for non-normal solar incidence. Typical pre-processing of CRISM data also includes other two steps: removing the isolated noise peak by destripe and rectifying columns deviation by despike. Coordinates from DDR will be utilized to build the map projection finally. Then, the minerals are identified through three main steps: judging data dimension, choosing end-member spectrum and spectral identification.

In this paper, using the SAM (spectral angle mapping) method to identified minerals. SAM is a physically-based spectral classification that uses an n-D angle to match pixels for reference spectra. The algorithm determines the spectral similarity between two spectra by calculating the angle between the spectra and treating them as vectors in a space with dimensionality equal to the number of bands. The SAM method compares the angle between the end member spectrum vector and each pixel vector in n-D space. Smaller angles represent closer matches to the reference spectrum [9].

\section{RESULTS AND DISCUSSION}

The spatial distribution of Minerals on Mars can provide relative geological information, which can be used for further analysis of the climate, environment, hydrology and habitability in the region. In this paper, we utilized the mixture tuned filtering (MTMF) and Spectral Angle Mapping (SAM) to get the spatial information of minerals. Using this process, the mineral spectral angle map is recognized at Jezero Crater, showed in Figure1.

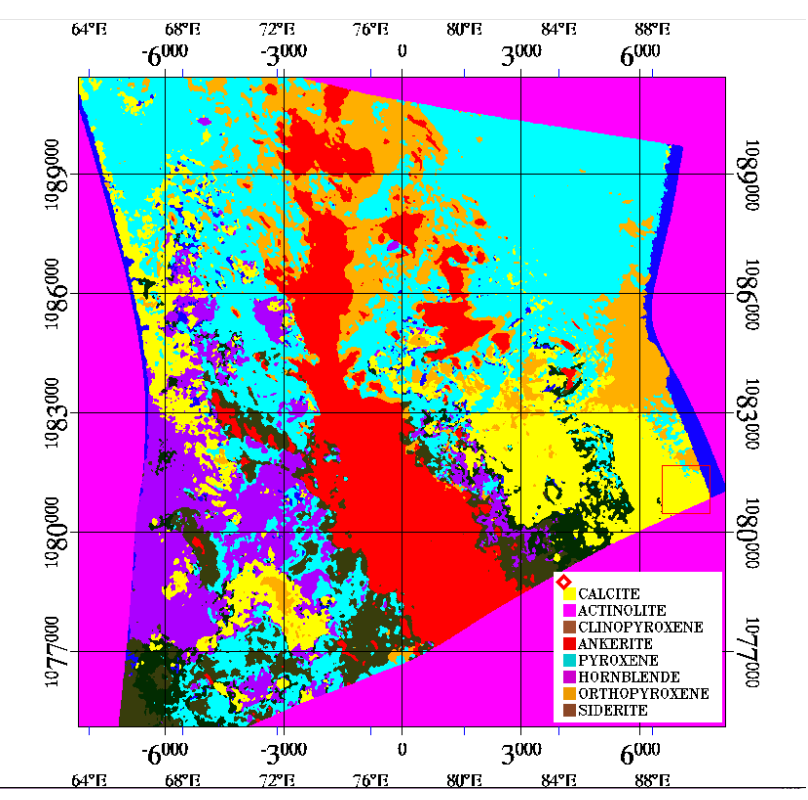

Figure 1. The mineral spectral angle map in Jezero Crater

After a detailed classification from the CRISM hyperspectral image, several minerals are detected in this area. Pyroxene represented by the turquoise color is the main component in this area. Most of the Pyroxene distributes on the north part and sparse Pyroxene spreads in other regions. The Calcite and Ankerite are the majority of the rest minerals. Ankerite represented by red color mainly distributed centrally like a gradation band, which can be easily discriminated from each other. Calcite represented by the yellow color is existed as clustered in the southeast part. The Actinolite, Hornblende and Orthopyroxene are very rare with similar proportion, which indicates that few of them can be identified. The possibility of the Clinopyroxene is very low due to the extremely low proportion. These detected minerals as the decreasing order of pixels are pyroxene, ankerite, calcite, siderite, actinolite, northupite and hornblende, respectively. Table 1 shows the detailed minerals detected at Jezero Crater. The detailed abundance analysis is described in Figure 2.

\begin{tabular}{|l|l|l|l|}
\hline $\begin{array}{l}\text { Mineral } \\
\text { name }\end{array}$ & Formular & Category & $\begin{array}{l}\text { Pixels } \\
\text { number }\end{array}$ \\
\hline pyroxene & $\begin{array}{l}(\mathrm{Ca}, \quad \mathrm{Na}, \mathrm{Fe}, \\
\mathrm{Mg})(\mathrm{Si}, \mathrm{Al})_{2} \mathrm{O}_{6}\end{array}$ & silicate & 163097 \\
\hline actinolite & $\mathrm{Ca}_{2}(\mathrm{Mg}, \mathrm{Fe})_{5} \mathrm{Si}_{8} \mathrm{O}_{22}(\mathrm{OH})_{2}$ & silicate & 33842 \\
\hline hornblende & $\begin{array}{l}\mathrm{Ca}_{2}(\mathrm{Mg}, \mathrm{Fe}, \mathrm{Al})_{5}(\mathrm{Al}, \\
\mathrm{Si})_{8} \mathrm{O}_{22}(\mathrm{OH})_{2}\end{array}$ & silicate & 13051 \\
\hline ankerite & $\mathrm{Ca}(\mathrm{Fe}, \mathrm{Mg}, \mathrm{Mn})(\mathrm{CO} 3)_{2}$ & carbonate & 51680 \\
\hline calcite & $\mathrm{CaCO}$ & carbonate & 44048 \\
\hline northupite & $\mathrm{Na}_{3} \mathrm{Mg}\left(\mathrm{CO}_{3}\right)_{2} \mathrm{Cl}$ & carbonate & 22086 \\
\hline siderite & $\mathrm{FeCO} 3$ & carbonate & 39658 \\
\hline
\end{tabular}

Table 1. Minerals detected by spectral angle detection 


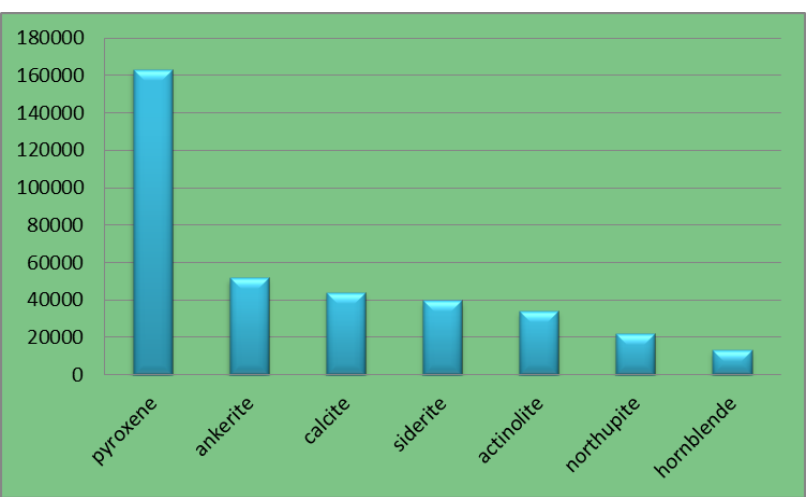

Figure 2. Mineral abundance in Jezero crater

From Table 1 and Figure 2, we can see that the dominated minerals in Jezero Crater are silicate and carbonate minerals. Silicate minerals include pyroxene, actinolite and hornblende, while carbonate minerals include ankerite, calcite, siderite and northupite.

Table 1 shows the Jezero crater was rich in Pyroxene. The Pyroxene is important classes of rock-forming mafic minerals, which are composed of basalt, dolerite and gabbro. The basaltic rock comprises the flat plains of lava flows called as flood basalts. The second-largest share of minerals is Ankerite, which is a class of carbonate consisting of calcium, iron, magnesium and manganese. Ankerite occurs with siderite in metamorphosed ironstones and sedimentary iron formations. Hence, the detection of ankerite suggests the sedimentary origin of Jezero Crater.

Actinolite and hornblende both are inosilicate minerals. Actinolite is produced by contact metamorphism of magnesium carbonate and mafic rocks in low-grade regional region. Hornblende is a common constituent of many igneous and metamorphic rocks, including granite, syenite, diorite, gabbro, basalt, andesite, etc. The presence of actinolite and hornblende indicates that the Jezero Crater has experienced the metamorphism besides the sedimentation.

Calcite and northupite account for the least proportion. However, they can give more important constraint on the ancient environment in this region. Calcite is carbonate minerals of calcium carbonate $(\mathrm{CaCO} 3)$, which is a common component of sedimentary rocks, limestone. Siderite is a carbonate mineral composed of iron. Siderite is mostly formed in hydrothermal vein and is associated with galena, fluorite and barite, etc. It is a common component of bedded sedimentary iron ores and metamorphic iron formations. Northupite is an uncommon evaporate mineral formed probably between 20$50^{\circ} \mathrm{C}$, as a lacustrine deposit or at depth in mud and clay. Its appearance is a strong evidence of the early warm and moist environment of Mars.

\section{CONCLUSION}

In this paper the distribution of the minerals in Jezero crater has been characterized in detail. By using the method of mixture tuned filtering (MTMF) and spectral angle mapper (SAM), some kind of minerals, silicate and carbonate, are identified as the major part in this region, including actinolite, ankerite, calcite, orthopyroxene, hornblende, siderite and northupite. The results have shown that pyroxene has dominated the proportion of $44 \%$ among all these minerals, followed by ankerite, calcite and siderite. The Hornblende accounts for the least proportion, about $4 \%$. These minerals suggest that the Jezero crater has experienced the sedimentation and metamorphism.

\section{REFERENCES}

1. Murchie S L, Mustard J F, Ehlmann B L, et al. A synthesis of Martian aqueous mineralogy after 1 Mars year of observations from the Mars Reconnaissance Orbiter[J]. Journal of Geophysical Research: Planets (1991-2012), 2009, 114(E2).

2. B. L. Ehlmann, J. F. Mustard, C. Fassett, S. C. Schon, J. W. Head III, D.J. Des Marais , et al., "Clay minerals in delta deposits and organic preservation potential on Mars," Nature Geoscience, vol. 1(6), 2008, pp. 355-358

3. P. R. Christensen,J. L. Bandfield,R. N. Clark,K. S. Edgett,V. E. Hamilton,T. Hoefen, et al., "Detection of crystalline hematite mineralization on Mars by the Thermal Emission Spectrometer: Evidence for near-surface water," J. Geophys. Res., vol. 105, 2000, pp. 9632-9642.

4. S. W. Squyres, J. P. Grotzinger, R. E. Arvidson, J. F. Bell III, W. Calvin, P. R. Christensen, et al., "In situ evidence for an ancient aqueous environment at Meridiani Planum, Mars," Science, vol. 306, 2004, pp.1709-1714

5. F. Poulet, J.-P. Bibring, J. F. Mustard, A. Gendrin, N. Mangold, Y. Langevin, et al., "Phyllosilicates on Mars andimplications for early martian climate," Nature, vol. 438, 2005, pp. 623-627.

6. J. -P. Bibring, Y. Langevin, J. F. Mustard, F. Poulet, R. Arvidson, , A Gendrin, et al., "Global mineralogical and aqueous Mars history derived from OMEGA/Mars Express data," Science, vol. 312, 2006, pp. 400-404.

7. B. L. Ehlmann, J. F. Mustard, G. A. Swayze, R. N. Clark, J. L. Bishop, F Poulet, et al., "Identification of hydrated silicate minerals on Mars using MRO-CRISM: Geologic context near Nili Fossae and implications for aqueous alteration," J. Geo. Res., vol. 114, 2009, doi:10.1029/2009JE003339.

8. S.M.Pelikey, et al, "CRISM multispectral summary products: Parameterizing minerals diversity on Mars from reflectance", Journal of geophysical research, vol.112,E08s14,doi:10.1029/2006JE002831,2007

9. F.A. Kruse, A.B. Lefkoff , J.W. Boardman, K.B. Heidebrecht, A.T. Shapiro, P.J. Barloon , et al., "The spectral image processing system (SIPS)-interactive visualization and analysis of imaging spectrometer data," Remote sensing of environment, vol. 44, 1993, pp. 145-163

10 S. L. Murchie, J. F. Mustard, B. L. Ehlmann, R. E. Milliken, J. L. Bishop, N. K. McKeown, et al. "A synthesis of Martian aqueous mineralogy after 1 Mars year of observations from the Mars Reconnaissance Orbiter," Journal of Geophysical Research, vol. 114, 2009, doi: 10.1029/2009JE003342 